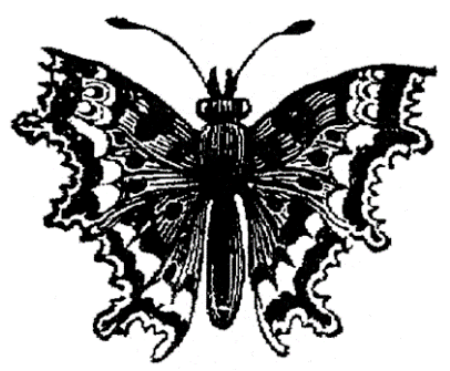

\title{
La Mariposa Mundial revista de literatura
}

\author{
Director Rodolfo Ortiz
}

\section{Pedidos:}

mariposamundial@gmail.com

\section{www.mariposamundial.com}

La Paz, Bolivia / Pittsburgh, PA

Bs. 40 (Bolivia) \$us 15 (exterior)

incluye costos de envio

\section{Próximamente: número 23}

Revistas literarias del siglo XIX - Revista de Revistas 